\title{
IMPLEMENTASI AKUNTANSI AGRIKULTUR PADA PERUSAHAAN SEKTOR PERTANIAN DI INDONESIA
}

\author{
RAVI CHOIRUL ANWAR, AMRIE FIRMANSYAH* \\ Jurusan Akuntansi, Politeknik Keuangan Negara STAN \\ *Email: amrie.firmansyah@gmail.com
}

\begin{abstract}
This study aims to review the implementation of agricultural accounting in Indonesia Agricultural Sector Companies. The research method used in this study is a qualitative method using content analysis. The data taken as the object of study are all the company's 2016-2018 annual financial statements which are the periods before and after the effective effect of PSAK 69 and PSAK 16 on agricultural sector companies listed on the Indonesia Stock Exchange. The objects are 14 companies. The results suggests that in the accounting treatment of biological assets and agricultural products, none of the companies implemented early adoption of PSAK 69 (2015) and apply accounting treatment in accordance with PSAK 69 in 2018. Related to biological assets in the form of productive plants, almost all companies have applied accounting treatment in accordance with PSAK 16 (revised 2015). The effectiveness of PSAK 69 (2015) provides significant changes to the accounting treatment of biological assets owned by companies, especially related to agricultural products. The treatment has an impact by increasing the company's assets by recognizing agricultural products as biological assets that were not previously recognized and recorded by the company. Meanwhile, related to biological assets in the form of live animals and edible plants that had been previously recognized by the company, there was a change in measurement using fair value less costs to sell, thereby affecting fluctuations in the company's profit and loss. The entry into force of PSAK 69 (2015) also uniforms the recognition and measurement of biological assets by companies.
\end{abstract}

Keywords: agricultural accounting, agriculture sector, accounting standards. 
Jurnal Ilmiah Akuntansi Universitas Pamulang - Vol. 8, No. 2, Juli 2020 - Anwar \& Firmansyah

\section{PENDAHULUAN}

Indonesia dikenal sebagai negara agraris karena memiliki sumber daya alam yang melimpah serta kondisi geografis yang strategis. Penduduk Indonesia pun sebagian besar bekerja di sektor pertanian. Mengacu pada data Badan Pusat Statistik (BPS), jumlah angkatan kerja di Indonesia pada Februari 2018 yang bekerja di sektor pertanian, kehutanan, dan perikanan mencapai angka 38,7 juta jiwa, atau sebesar 30,45\% dari seluruh angkatan kerja (https://www.bps.go.id/). Sektor pertanian juga berkontribusi besar terhadap Produk Domestik Bruto (PDB) Indonesia sebesar 9,93\% dalam pertumbuhan PDB triwulan II tahun 2018 (https://www.bps.go.id/). Berdasarkan data tersebut, diketahui bahwa sektor pertanian menjadi pilar penting dalam perekonomian Indonesia.

Lingkungan bisnis dalam sektor pertanian merupakan usaha di bidang pertanian yang mencari laba dengan menghasilkan produk pertanian dengan segala karakteristiknya Hastuti (2017). Agrobisnis menjadi perhatian tersendiri sebagai sektor yang menjadi tonggak utama dalam menggerakkan perekonomian Indonesia. Sektor pertanian ini meliputi subsektor tanaman pangan, perkebunan, kehutanan, peternakan, dan perikanan. Sektor ini menghasilkan berbagai macam komoditas eskpor, antara lain yaitu padi, jagung, kedelai, karet, kelapa sawit, tembakau, kapas, kopi, tebu, dll. (https://ekonomi.kompas.com)

Pertumbuhan sektor pertanian sudah cukup baik dan berkontribusi cukup besar terhadap PDB, tetapi bukan berarti sektor ini sudah terbebas dari banyak masalah. Masih banyak permasalahan dalam sektor pertanian, mulai dari pengelolaan persediaan, harga berbagai komoditas yang sering bergejolak, praktik curang atau fraud dalam rantai distribusi pangan, hingga kesulitan dalam mencari sumber pembiayaan yang mengakibatkan minimnya modal bagi perusahaan (https://ekonomi.kompas.com). Permasalahan dalam modal disebut menjadi yang paling utama. Saptia (2017), menyatakan bahwa masalah utama yang dihadapi untuk mendorong produktivitas pangan adalah sumber pembiayaan, terutama dari lembaga keuangan formal (www.wartaekonomi.co.id). Bahkan, dari banyaknya perusahaan yang bergerak dalam sektor pertanian ini, jumlah perusahaan yang terdaftar di BEI hanya sebanyak 21 perusahaan berdasarkan data dari www.idx.co.id per tanggal 19 Desember 2018. Mengingat Indonesia adalah negara agraris, jumlah tersebut bisa dibilang sedikit. Padahal, menjual saham secara publik menjadi salah satu solusi dalam permasalahan sulitnya mencari modal. Dengan menjadi go public, perusahaan juga akan memperoleh berbagai manfaat, diantaranya yaitu meningkatkan nilai perusahaan, meningkatkan image perusahaan, insentif pajak, dan meningkatnya kemampuan untuk mempertahankan kelangsungan usaha (https://gopublic.idx.co.id/).

Salah satu hal yang harus menjadi fokus perhatian dalam menangani berbagai masalah tersebut adalah pelaporan keuangan. Perusahaan harus mampu membuat laporan keuangan yang andal karena informasi keuangan sangat penting baik bagi investor, kreditur, pemerintah, maupun manajemen perusahaan itu sendiri. PSAK 1 (IAI, 2015) mengungkapkan bahwa laporan keuangan bertujuan untuk memberikan informasi mengenai posisi keuangan, kinerja keuangan, dan arus kas entitas, yang 
Jurnal Ilmiah Akuntansi Universitas Pamulang - Vol. 8, No. 2, Juli 2020 - Anwar \& Firmansyah

bermanfaat bagi sebagian besar pengguna laporan keuangan dalam pengambilan keputusan. Laporan keuangan juga menunjukkan hasil pertanggungjawaban manajemen atas penggunaan sumber daya yang dipercayakan kepada mereka. Laporan keuangan tentunya akan sangat membantu bagi manajemen perusahaan sektor pertanian dalam mengembangkan usahanya karena dari laporan keuangan dapat diambil keputusan ekonomi secara lebih akurat. Selain itu, dari laporan keuangan, manajemen dapat memeroleh berbagai manfaat, diantaranya yaitu dapat mengetahui kondisi bisnis perusahaan yang sebenarnya secara lebih akurat, mengidentifikasi terjadinya praktik curang dalam proses operasi, merekam berbagai peristiwa penting seperti gejolak harga, dan menggunakan laporan keuangan sebagai alat untuk mencari sumber pembiayaan seperti melakukan initial public offering (IPO) atau mengajukan kredit ke lembaga keuangan formal.

Laporan keuangan yang andal tentunya membutuhkan akuntansi yang mampu mencatat semua transaksi dengan tepat dan sesuai dengan standar yang berlaku, serta dibutuhkan penentuan kebijakan akuntansi perusahaan yang relevan dengan proses bisnisnya. Standar akuntansi di Indonesia sendiri diatur dalam Pernyataan Standar Akuntansi Keuangan (PSAK) yang dibuat oleh IAI, di mana sudah terdapat banyak PSAK yang mengatur secara berbeda dari beragam transaksi atau peristiwa. Dalam sektor pertanian, akuntansi terkait aset biologis dan produk agrikultur menjadi perhatian tersendiri, karena proses bisnis perusahaan dalam sektor ini tidak bisa terlepas dari aktivitas agrikultur. Aset biologis sendiri dalam PSAK 69 (IAI, 2015) yaitu hewan atau tanaman hidup, contohnya yaitu tumbuhan padi, pohon kelapa sawit, hewan ternak, ikan, dsb. Sementara itu, produk agrikultur yaitu produk yang dipanen dari aset biologis milik perusahaan, contohnya buah, susu, dan sebagainya. Pencatatan terkait aset biologis dan produk agrikultur yang sesuai standar diharapkan dapat menggambarkan kondisi bisnis perusahaan secara lebih relevan. Namun, standar akuntansi yang mengatur secara eksplisit tentang aset biologis dan produk agrikultur di Indonesia, yaitu PSAK 69 (IAI, 2015), baru disahkan pada akhir tahun 2015 dan baru akan berlaku efektif mulai 1 januari 2018 dengan penerapan dini dianjurkan. Berlakunya PSAK 69 (IAI, 2015) ini berkaitan erat dengan berlakunya PSAK 16 (IAI, 2015) karena dalam PSAK 69 (IAI, 2015) dinyatakan bahwa aset biologis berupa tanaman produktif dikecualikan dari ruang lingkup PSAK 69 (IAI, 2015) dan masuk ke dalam ruang lingkup PSAK 16 (IAI, 2015) yang juga akan berlaku efektif mulai 1 Januari 2018.

Berlakunya PSAK 69 (IAI, 2015) dan PSAK 16 (IAI, 2015) ini tidak menetapkan ketentuan transisi tertentu, tetapi penerapan dini sebelum tanggal 1 Januari 2018 dianjurkan. Penerapan pernyataan ini dicatat sesuai PSAK 25 (IAI, 2015) tentang kebijakan akuntansi, perubahan estimasi akuntansi, dan kesalahan. Sebelum PSAK 69 (IAI, 2015) dan PSAK 16 (IAI, 2015) berlaku, perusahaan dapat mengacu pada International Accounting Standard (IAS) 41 agriculture dalam perlakuan akuntansi terhadap aset biologis dan produk agrikultur, sebagaimana Indonesia melalui IAI sudah menyatakan berlakunya konvergensi International Financial Reporting Standard (IFRS) sejak tahun 2012 (https://finance.detik.com/).

IFRS yang awalnya memasukkan semua aset biologis dalam ruang lingkup IAS 41 (2008) sempat mengundang kontoversi, terutama terkait bearer biological asset (BBA). BBA adalah aset biologis yang dimiliki untuk menghasilkan produk 
Jurnal Ilmiah Akuntansi Universitas Pamulang - Vol. 8, No. 2, Juli 2020 - Anwar \& Firmansyah

agrikultur, contohnya adalah pohon kelapa sawit yang menghasilkan tandan buah segar atau tanaman sagu yang menghasilkan produk sagu. Sementara itu, tidak terdapat masalah berarti untuk consumable biological assets (CBA). CBA adalah aset biologis yang akan dipanen sebagai produk agrikultur atau dijual sebagai aset biologis, contohnya yaitu pohon kayu. Elad \& Herbohn (2011) menyatakan bahwa pengukuran BBA berdasar nilai wajar atau fair value selain menimbulkan fluktuasi laba yang tidak relevan, pengukurannya juga sulit dilakukan dalam perusahaan perikanan dan perkebunan, sehingga menimbulkan anggapan bahwa biaya yang dikeluarkan untuk mengukur nilai wajar lebih besar daripada manfaat yang didapatkan. Di lain pihak, Argiles et al (2011) mendukung pengukuran berdasar nilai wajar dan menyatakan bahwa metode biaya perolehan untuk mengukur aset biologis kurang informatif dengan alasan karakteristik aset biologis yang terus menerus berubah.

Pada kurun waktu itu, negara-negeara seperti Indonesia, Malaysia, dan India mengalami ganjalan dalam mengadopsi IAS 41 (2008) ini. Untuk menengahi masalah ini, Asian-Oceanian Standard-Setters Group (AOSSG) membantu menyuarakan kepentingan kawasan Asia dan Ocenia dengan mengusulkan BBA sebaiknya diizinkan menggunakan metode biaya (iaiglobal.or.id). Pada tahun 2014, akhirnya IFRS melakukan amandemen terkait IAS 41 dan IAS 16 dengan memasukkan aset biologis berupa tanaman produktif ke dalam ruang lingkup plant, property, and equipment dalam IAS 16 (2014). Sementari itu, aset biologis berupa hewan dan consumable biological asset (CBA) tetap masuk ke dalam ruang lingkup IAS 41 (2014). Selanjutnya, IAI selaku badan penyusun standar akuntansi di Indonesia mengadopsi IAS 41 (2014) secara penuh yang tertuang dalam PSAK 69 (IAI, 2015). Berkaitan dengan itu, IAI juga melakukan amandemen PSAK 16 (IAI, 2015) terkait dengan tanaman produktif.

Penelitian terkait metode pengukuran yang sesuai untuk aset biologis pernah dilakukan oleh Bohusova \& Svoboda (2016) dengan kesimpulan bahwa metode biaya cocok untuk tanaman produktif (bearer plants), sedangkan metode nilai wajar cocok untuk hewan hidup. Penelitian terkait penerapan akuntansi aset biologis pernah dilakukan oleh Farida (2013) yang menganalisis penerapan IAS 41 (2008) pada perusahaan PT. Perkebunan Nusantara VII (PTPN VII) dengan kesimpulan PTPN VII belum menerapkan perlakuan akuntansi yang sesuai dengan IAS 41 (2008) yang berlaku pada saat itu. Pada saat itu, PTPN VII mengakui produk agrikultur sebagai persediaan sebesar biaya perolehannya, berbeda dengan perlakuan akuntansi dalam IAS 41 (2008) di mana produk agrikultur diakui sebagai aset biologis sebesar nilai wajarnya. Sementara itu, Listyawati \& Firmansyah (2018) melakukan penelitian yang mengevaluasi perlakuan akuntansi aset biologis pada sebuah entitas tanpa akuntabilitas publik, yaitu CV Sumber Berkat dan menyimpulkan pada saat itu objek masih menerapkan perlakuan akuntansi yang tergolong sederhana dan secara keseluruhan berbeda dengan perlakuan akuntansi atas aset biologis dalam PSAK 69 (IAI, 2015). Berhubung PSAK 69 (IAI, 2015) dan PSAK 16 (IAI, 2015) baru disahkan pada tahun 2015 dan baru berlaku efektif pada 1 Januari 2018, belum ada penelitian terkait dengan analisis perbandingan perlakuan akuntansi pada perusahaan subsektor perkebunan sebelum dan sesudah berlaku efektifnya PSAK 69 (IAI, 2015) dan PSAK 16 (IAI, 2015). 
Jurnal Ilmiah Akuntansi Universitas Pamulang - Vol. 8, No. 2, Juli 2020 - Anwar \& Firmansyah

Oleh karena itu, perlu untuk mengetahui perlakuan akuntansi terkait agrikultur pada perusahaan subsektor perkebunan yang terdaftar di BEI beberapa tahun terakhir serta perbandingan perlakuan tersebut sebelum dan sesudah berlaku efektifnya PSAK 69 (IAI, 2015). Penelitian ini bertujuan untuk mengulas perlakuan aset biologis dan produk agrikultur masing-masing perusahan dalam laporan keuangan perusahaan tahun 2016-2018. Selain itu, penelitian ini menganalisis perbandingan perlakuan akuntansi dari seluruh perusahaan subsektor perkebunan secara keseluruhan sebelum dan sesudah berlaku efektifnya PSAK 69 (2015) dan PSAK 16 (IAI, 2015). Dari berbagai subsektor yang terdapat pada sektor pertanian, penelitian ini memilih subsektor perkebunan sebagai objek karena aktivitas agrikultur pada subsektor tersebut melibatkan banyak aset biologis dan menghasilkan berbagai produk agrikultur.

\section{LANDASAN TEORI}

Menurut PSAK 69 (IAI, 2015), aset biologis adalah hewan atau tumbuhan hidup, yang dapat berupa tumbuhan padi, kelapa sawit, hewan ternak, dan ikan. Karakteristik yang membedakan aset biologis dengan aset yang lain adalah aset biologis mengalami transformasi biologis yang meliputi pertumbuhan, degenerasi, produksi, dan prokreasi yang mengakibatkan perubahan kualitatif atau kuantitatif suatu aset biologis (IAI, 2015). Dalam PSAK 69 (IAI, 2015), aset biologis yang dimiliki entitas nantinya dapat menghasilkan produk agrikultur yaitu produk hasil panen dari aset biologis milik perusahaan. Contoh produk agrikultur adalah susu, yang merupakan produk yang dihasilkan oleh aset biologis berupa sapi, dan daun teh, yang merupakan hasil panen dari tumbuhan teh. Produk agrikultur atau hasil panen dari aset biologis dapat langsung dijual ataupun diolah kembali. Produk yang diolah kembali akan menjadi produk yang merupakan hasil pemrosesan setelah panen, contohnya keju, yang merupakan olahan dari susu, dan teh celup, yang merupakan olahan dari daun teh.

Aset biologis dapat diklasifikasikan ke dalam berbagai kategori sesuai karakteristiknya. Klasifikasi tersebut sangat penting karena perbedaan karakteristik memengaruhi perlakuan akuntansi aset biologis tersebut. Dalam PSAK 69 (IAI, 2015), disebutkan bahwa aset biologis dapat dibedakan menjadi aset biologis produktif/bearer biological assets (BBA) dan aset biologis yang dapat dikonsumsi/consumable biological assets (CBA). BBA merupakan aset biologis yang nantinya menghasilkan produk agrikultur atau aset biologis lainnya. Contohnya adalah tanaman kelapa sawit yang menghasilkan tandan buah segar, tanaman karet yang menghasilkan getah, dan sapi yang menghasilkan susu. Sementara itu, CBA merupakan aset biologis yang nantinya dipanen sebagai produk agrikultur atau untuk tujuan dijual. Contohnya adalah pohon dalam hutan kayu yang nantinya ditebang untuk dijual atau diolah menjadi suatu produk.

Selain itu, dalam PSAK 69 (IAI, 2015), disebutkan juga tanaman semusim. Menurut Syafrezani (2009), tanaman semusim adalah tanaman yang berkecambah, tumbuh, berbunga, menghasilkan biji, dan mati hanya dalam setahun atau bahkan kurang. Sementara itu, jenis tanaman perkebunan yang umumnya berumur lebih dari satu tahun merupakan tanaman tahunan (Ayu et al, 2015). Tanaman semusim 
Jurnal Ilmiah Akuntansi Universitas Pamulang - Vol. 8, No. 2, Juli 2020 - Anwar \& Firmansyah

(annual) contohnya adalah jagung dan gandum, sedangkan tanaman tahunan (perennial) contohnya adalah tanaman sawit, tanaman karet, teh, dan lada. Pengelompokan tanaman berdasarkan jenisnya sangat penting, termasuk pengelompokkan tanaman semusim atau tahunan karena perbedaan perlakuan akuntansi atas kedua kategori tersebut.

Dari berbagai informasi di atas, berdasarkan karaktersitik dan perlakuan akuntansi, tumbuhan hidup dapat dikelompokkan menjadi tanaman tahunan dan tanaman semusim. Tanaman tahunan dapat dikelompokkan lagi menjadi bearer plants dan consumable plants. Sementara itu aset hewan dapat dikelompokkan menjadi bearer animals dan consumable animals. Di Indonesia, standar akuntansi yang mengatur aktivitas agrikultur baru disahkan pada penghujung tahun 2015, tepatnya tanggal 16 Desember 2015 (http://iai.global.or.id). Dewan Standar Akuntansi Keuangan (DSAK) menetapkan PSAK 69 (2015) tentang agrikultur yang akan berlaku efektif tanggal 1 Januari 2018. DSAK juga mengamandemen PSAK 16 pada tahun 2015 untuk memasukkan tanaman produktif ke dalam ruang lingkup aset tetap.

Dari klasifikasi aset biologis yang telah dipaparkan sebelumnya, aset biologis berupa hewan baik itu bearer animals ataupun consumable animals masuk dalam ruang lingkup PSAK 69 (IAI, 2015). Tanaman musiman dan tanaman tahunan kelompok consumable plants masuk ke dalam ruang lingkup PSAK 69 (IAI, 2015). Produk agrikultur juga diatur dalam PSAK 69. Sementara itu, tanaman tahunan jenis bearer plants masuk ke dalam ruang lingkup PSAK 16 (IAI, 2015). PSAK 69 (IAI, 2015) menyatakan bahwa yang termasuk dalam ruang lingkup PSAK ini yaitu aset biologis kecuali tanaman produktif dan produk agrikultur. Termasuk dalam ruang lingkup ini yaitu aset biologis yang diperoleh dari hibah pemerintah. Pernyataan ini mengatur aset biologis berupa hewan baik bearer animals maupun consumable animals, tanaman tahunan jenis consumable plants, tanaman semusim, dan produk agrikultur. Sementara itu, tanaman produktif (bearer plants) tidak termasuk dalam ruang lingkup pernyataan ini. Namun, produk yang tumbuh pada tanaman produktif tersebut tetap termasuk dalam ruang lingkup pernyataan ini.

Terkait pengakuan aset biologis dan produk agrikultur, PSAK 69 (IAI, 2015) menyatakan bahwa aset biologis dan produk agrikultur dapat diakui apabila perusahaan memiliki kendali atas aset biologis atau produk agrikultur sebagai akibat dari peristiwa masa lalu, besar kemungkinan adanya aliran manfaat ekonomi masa depan dari aset biologis atau produk agrikultur, dan nilai wajar atau biaya perolehan aset biologis atau produk agrikultur dapat diukur secara andal. Aset biologis tersebut diukur pada nilai wajar dikurangi biaya untuk menjual (net realizable value) pada saat pengakuan awal dan pada setiap akhir periode pelaporan. Kieso et al. (2017) menjelaskan bahwa istilah net realizable value merujuk pada ekspektasi nilai bersih yang akan didapat oleh perusahaan atas penjualan persediaan. Sementara itu, menurut PSAK 69 (IAI, 2015) nilai wajar (fair value) merupakan harga yang akan diterima apabila menjual suatu aset atau harga yang akan dibayar untuk mengalihkan suatu liabilitas dalam sebuah transaksi antara pelaku pasar pada tanggal pengukuran. Aset biologis akan dinilai pada nilai bersih yang perusahaan eskpektasikan dari realisasi aset biologis tersebut apabila dijual. Dalam PSAK 69 (IAI, 2015) diatur bahwa produk agrikultur yang dipanen dari aset biologis milik entitas juga diukur pada nilai wajar dikurangi biaya untuk menjual (net realizable value) pada titik panen. Pada saat 
Jurnal Ilmiah Akuntansi Universitas Pamulang - Vol. 8, No. 2, Juli 2020 - Anwar \& Firmansyah

produk agrikultur tersebut dipanen, Net realizable value ini akan menjadi biaya perolehan (cost), kemudian produk agrikultur diperlakukan mirip dengan persediaan pada umumnya (Kieso et al, 2017).

Pengukuran pada net realizable value dapat menimbulkan keuntungan atau kerugian pada saat pengakuan awal maupun akibat perubahan net realizable value tersebut. Net realizable value umumnya berubah dari waktu ke waktu, sehingga pada saat pelaporan, di mana perusahaan akan mengukur aset biologis dan produk agrikultur pada net realizable value-nya, timbul keuntungan apabila net realizable value lebih besar dari nilai tercatat atau kerugian apabila net realizable value lebih kecil dari nilai tercatat. Keuntungan atau kerugian tersebut akan memengaruhi laba rugi pada periode terjadinya.

Untuk mengukur nilai wajar yang digunakan dalam perhitungan net realizable value, perusahaan menggunakan teknik penilaian tertentu yang sesuai dengan keadaan. Perusahaan akan mengumpulkan data yang tersedia untuk mengukur nilai wajar, kemudian akan memaksimalkan penggunaan input relevan yang dapat diobservasi, dan meminimalkan penggunaan input yang tidak dapat diobservasi sebagaimana diatur dalam PSAK 68 (IAI, 2015). Entitas dapat memilih input yang konsisten dengan karakteristik aset yang akan diperhitungkan pelaku pasar dalam transaksi untuk aset tersebut. Untuk meningkatkan konsistensi dan keterbandingan dalam pengukuran nilai wajar dan pengungkapannya, PSAK 68 (IAI, 2015) telah menetapkan hierarki nilai wajar yang terbagi dalam tiga level input. Input level 1 adalah harga kuotasian (tanpa penyesuaian) di pasar aktif untuk aset yang identik yang dapat diakses entitas pada tanggal pengukuran. Input level 2 adalah input selain harga kuotasian yang termasuk dalam level 1 yang dapat diobservasi untuk aset, baik secara langsung maupun tidak langsung, misalnya yaitu harga kuotasian yang serupa di pasar aktif atau di pasar yang tidak aktif, input selain dari harga kuotasian yang dapat diobservasi untuk aset, dan input yang diperkuat pasar. Input level 3 adalah input yang tidak dapat diobservasi untuk aset. Input ini digunakan apabila tidak ada input selain harga kuotasian yang dapat diobservasi. Setelah entitas memilih input level yang digunakan dalam teknik penilaian, teknik penilaian yang digunakan untuk mengukur nilai wajar tersebut diterapkan secara konsisten. Secara luas terdapat tiga teknik penilaian yang digunakan, yaitu pendekatan pasar, pendekatan biaya, dan pendekatan penghasilan.

Aset biologis seringkali secara fisik melekat pada tanah (contohnya pepohonan dalam hutan). Mungkin tidak terdapat pasar terpisah untuk aset biologis yang melekat tersebut, sehingga tidak terdapat harga atau nilai wajar bagi aset biologis tersebut. Namun, mungkin saja terdapat pasar aktif untuk aset gabungan sebagai suatu kesatuan. Dalam PSAK 69 (IAI, 2015), perusahaan dapat menggunakan informasi mengenai aset gabungan tersebut untuk mengukur nilai wajar aset biologis. Terdapat asumsi bahwa nilai wajar aset biologis dapat diukur secara andal. Asumsi tersebut dapat dibantah, tetapi hanya pada saat pengakuan awal aset biologis yang harga pasarnya tidak tersedia dan alternatif pengukuran nilai wajarnya tidak dapat diandalkan. Apabila hal tersebut terjadi, perusahaan dapat mengukur aset biologis pada biaya perolehannya dikurangi akumulasi penyusutan dan akumulasi kerugian penurunan nilai. Terkadang net realizable value suatu aset biologis tidak dapat ditentukan karena nilai wajar tidak dapat diukur secara andal menggunakan input 
Jurnal Ilmiah Akuntansi Universitas Pamulang - Vol. 8, No. 2, Juli 2020 - Anwar \& Firmansyah

level berapapun. Sehingga, aset biologis diukur pada cost dikurang dengan akumulasi penyusutan dan penurunan nilainya.

Penyajian suatu aset termasuk aset biologis pada laporan keuangan entitas diatur dalam PSAK 1 (IAI, 2015) tentang penyajian laporan keuangan, penyajian suatu aset diklasifikasikan secara terpisah sesuai masa manfaatnya. Aset yang memiliki masa manfaat kurang dari periode akuntansi disajikan sebagai aset lancar. Sebaliknya, aset yang memiliki masa manfaat lebih dari periode akuntansi disajikan sebagai aset tidak lancar. Aset biologis ada yang memiliki masa manfaat kurang dari periode akuntansi dan ada yang memiliki masa manfaat lebih dari periode akuntansi. Oleh karena itu, aset biologis dapat tergolong aset lancar atau aset tidak lancar tergantung masa manfaat aset biologis tersebut.

Dalam hal pengungkapan terkait aset biologis dan produk agrikultur, PSAK 69 (IAI, 2015) mensyaratkan perusahaan untuk melakukan pengungkapan. Pertama, Perusahaan mengungkapkan keuntungan atau kerugian gabungan yang timbul selama periode berjalan pada saat pengakuan awal aset biologis dan produk agrikultur, dan dari perubahan nilai wajar dikurangi biaya untuk menjual aset biologis. Terkait perubahan net realizable value aset biologis, perusahaan dianjurkan untuk mengungkapkan berdasarkan kelompok atau klasifikasi lainnya. Perusahaan juga dianjurkan untuk memisahkan jumlah perubahan net realizable value antara yang diakibatkan perubahan fisik dan yang diakibatkan perubahan harga. Kedua, perusahaan mendeskripsikan setiap kelompok aset biologis. Terkait pengelompokkan ini, entitas dianjurkan untuk membedakan antara aset biologis yang dapat dikonsumsi (consumable biological assets) dan aset biologis produktif (bearer biological assets), atau antara aset biologis menghasilkan (mature) dan yang masih belum menghasilkan (immature), sesuai keadaan aset biologis. PSAK 69 (2015) tidak memberikan dasar pengelompokkan yang sifarnya wajib diikuti. Perusahaan dapat membuat pengelompokkan sendiri sesuai keadaan aset biologis dan mengungkapkan dasar pengelompokkan tersebut dalam catatan atas laporan keuangan. Ketiga, Jika deskripsi di atas tidak diungkapkan, perusahaan disyaratkan untuk melakukan pengungkapan yang lain. Perusahaan disyaratkan mendeskripsikan sifat aktivitasnya yang melibatkan setiap kelompok aset biologis. Perusahaan mengungkapkan jumlah fisik setiap kelompok aset biologis dan total output produk agrikultur selama periode tersebut. Keempat, perusahaan mengungkapkan keberadaan dan jumlah tercatat aset biologis yang kepemilikannya dibatasi, dan jumlah tercatat aset biologis yang dijaminkan untuk liabilitas apabila ada. Jumlah komitmen untuk pengembangan atau akuisisi aset biologis juga harus diungkapkan apabila terdapat komitmen kepada pihak lain. Perusahaan juga disyaratkan mengungkapkan strategi manajemen risiko keuangan yang terkait aktivitas agrikultur apabila ada. Kelima, perusahaan menyajikan rekonsiliasi perubahan jumlah tercatat aset biologis antara awal dan akhir periode berjalan. Rekonsiliasi tersebut mencakup keuntungan atau kerugian yang timbul dari perubahan net realizable value, kenaikan karena pembelian, penurunan akibat penjualan atau reklasifikasi, penurunan karena panen, kenaikan yang dihasilkan dari kombinasi bisnis, selisih kurs, dan perubahan lain.

Pada bagian pengakuan dan pengukuran, telah dijelaskan juga bahwa mungkin terdapat aset biologis yang nilai wajarnya tidak dapat diukur secara andal. Apabila entitas memiliki aset biologis tersebut, diperlukan pengungkapan tambahan 
Jurnal Ilmiah Akuntansi Universitas Pamulang - Vol. 8, No. 2, Juli 2020 - Anwar \& Firmansyah

berdasarkan PSAK 69 (IAI, 2015), alasan nilai wajar tidak dapat diukur secara andal, rentang estimasi kemungkinan nilai wajar aset tersebut, metode penyusutan yang digunakan, masa manfaat, serta jumlah tercatat bruto dan akumulasi penyusutan pada awal dan akhir periode.

Setelah PSAK 16 mengalami amandemen tahun 2015, tanaman produktif masuk dalam ruang lingkup aset tetap. Aset tetap sendiri menurut PSAK 16 (IAI, 2015) yaitu aset berwujud yang dimiliki untuk digunakan dalam produksi atau penyediaan barang atau jasa, untuk direntalkan kepada pihak lain, atau untuk tujuan administratif, dan diperkirakan untuk digunakan selama lebih dari satu periode. Tanaman produktif diakui sebagai aset saat besar kemungkinan manfaat ekonomi akan mengalir ke perusahaan di masa depan berkenaan dengan aset tersebut dan biaya perolehan dapat diukur secara andal. Tanaman produktif diakui layaknya aset tetap sebesar biaya perolehan dan diperlakukan dengan cara yang sama dengan aset tetap yang dibangun/dikonstruksi sendiri sebelum berada dalam kondisi yang diperlukan untuk siap digunakan tersebut menghasilkan. Acuan "konstruksi" tersebut mencakup aktivitas yang diperlukan untuk membudidayakan tanaman produktif mulai dari tanaman belum menghasilkan hingga menjadi tanaman menghasilkan. Tanaman belum menghasilkan akan dinilai sebesar biaya perolehannya, kemudian biaya-biaya yang terjadi berkaitan dengan pengembangan tanaman akan dikapitalisasi dan tidak disusutkan sampai tanaman tersebut menghasilkan. Biaya perolehan tersebut diantarnya meliputi biaya pembibitan, penanaman, pemupukan, dan pemeliharaan. Pada saat tanaman sudah menghasilkan, akumulasi harga perolehan tersebut akan direklasifikasi ke tanaman menghasilkan dan mulai disusutkan dengan menggunakan metode penyusutan yang konsisten. Dalam PSAK 16 (IAI, 2015), metode penyusutan yang dapat digunakan antara lain metode garis lurus, metode saldo menurun, dan metode unit produksi. Perusahaan dapat memilih metode yang paling mencerminkan pola pemakaian yang diperkirakan atas manfaat ekonomi masa depan tanaman produktif tersebut.

PSAK 16 (IAI, 2015) mengatur bahwa selain menggunakan model biaya (cost model) seperti dijelaskan di atas, perusahaan dapat memilih menggunakan model revaluasi. Dalam model revaluasi, tanaman produktif dicatat pada jumlah revaluasian, yaitu nilai wajar pada tanggal revaluasi dikurangi akumulasi penyusutan dan akumulasi rugi penurunan nilai setelah tanggal revaluasi. Model ini dapat digunakan apabila nilai wajar dari tanaman produktif dapat diukur secara andal. Dalam hal pengungkapan, berdasarkan PSAK 16 (IAI, 2015), perusahan disyaratkan untuk mengungkapkan dasar pengukuran yang digunakan, metode penyusutan, umur manfaat, jumlah tercatat bruto dan akumulasi penyusutan pada awal dan akhir periode, serta rekonsiliasi jumlah tercatat pada awal dan akhir periode. Jika perusahaan menggunakan model revaluasi, terdapat beberapa pengungkapan tambahan yang disyaratkan, yaitu tanggal efektif revaluasi, keterlibatan penilai independen, jumlah tercatat seandainya aset tersebut dicatat dengan model biaya, dan surplus revaluasi. 
Jurnal Ilmiah Akuntansi Universitas Pamulang - Vol. 8, No. 2, Juli 2020 - Anwar \& Firmansyah

\section{METODOLOGI PENELITIAN}

Metode yang digunakan dalam penelitian ini adalah metode kualitatif melalui pendekatan content analysis. Data yang diambil sebagai objek penelitian ini adalah seluruh laporan keuangan tahunan perusahaan periode 2016-2018 yang merupakan periode sebelum dan setelah berlaku efektifnya PSAK 69 (2015) dan PSAK 16 (IAI, 2015) pada perusahaan agrikultur. Sampel yang digunakan adalah perusahaan subsektor perkebunan yang telah melakukan initial public offer (IPO) sebelum 2017, ke atas tidak termasuk dalam ruang lingkup penelitian ini. Dari total enam belas perusahaan subsektor perkebunan yang terdaftar di BEI sejak periode 2016, terdapat dua perusahaan yang tidak termasuk sebagai objek penelitian ini, yaitu PT. Golden Plantation Tbk. dan PT. Multi Agro Gemilang Plantation Tbk, karena pada saat penelitian ini dilakukan belum mengeluarkan laporan keuangan tahun 2018. Sementara itu, PT. Multi Agro Gemilang Plantation Tbk. tidak dimasukkan ke dalam objek penelitian karena perusahaan tersebut tidak memiliki aset biologis akibat proses bisnisnya yang berbeda dari perusahaan subsektor perkebunan yang lain. Adapun sampel yang digunakan sebagai objek penelitian adalah sebegai berikut:

Tabel 1

Data Sampel Perusahaan Terpilih

\begin{tabular}{cllc}
\hline No. & Kode & \multicolumn{1}{c}{ Nama Emiten } & Tanggal IPO \\
\hline 1 & AALI & PT. Astra Agro Lestari Tbk. & 9 Desember 1997 \\
2 & ANJT & PT. Austindo Nusantara Jaya Tbk & 10 Mei 2013 \\
3 & BWPT & PT. Eagle High Plantations Tbk & 27 Oktober 2009 \\
4 & DSNG & PT. Dharma Satya Nusantara Tbk. & 14 Juni 2013 \\
5 & GZCO & PT. Gozco Plantations Tbk. & 15 Mei 2008 \\
6 & JAWA & PT. Jaya Agra Wattie Tbk. & 30 Mei 2011 \\
7 & LSIP & PT. London Sumatera Indonesia Tbk. & 5 Juli 1996 \\
8 & PALM & PT. Provident Agro Tbk. & 18 Oktober 2012 \\
9 & SGRO & PT. Sampoerna Agro Tbk. & 18 Juni 2007 \\
10 & SIMP & PT. Salim Ivomas Pratama Tbk. & 9 Juni 2011 \\
11 & SMAR & PT. Sinar Mas Agro Resources and Technology Tbk. & 20 November 1992 \\
12 & SSMS & PT. Sawit Sumbermas Sarana Tbk. & 12 Desember 2013 \\
13 & TBLA & PT. Tunas Baru Lampung Tbk. & 14 Februari 2000 \\
14 & UNSP & PT. Bakrie Sumatera Plantations Tbk. & 6 Maret 1990 \\
\hline
\end{tabular}

Sumber: data diolah

\section{HASIL PENELITIAN DAN PEMBAHASAN}

Empat belas perusahaan yang menjadi objek dalam penelitian ini memiliki berbagai aset biologis yang dapat diklasifikasikan menjadi hewan hidup, tanaman tahunan jenis tanaman produktif (bearing biological plants), tanaman tahunan jenis tanaman yang dapat dikonsumsi (consumable biological plants), tanaman semusim, dan juga produk agrikultur. Aset hewan hanya dimiliki oleh AALI, yaitu berupa sapi. Bearing biological plants dimiliki oleh seluruh perusahaan yang sebagian berupa kelapa sawit dan karet. Consumable biological plants dimiliki oleh DSNG dan SIMP berupa pohon dalam hutan kayu dan hutan tanaman industri. Tanaman semusim dimiliki oleh ANJT, yaitu kacang edamame, dan TBLA, yaitu tebu. Produk agrikultur 
Jurnal Ilmiah Akuntansi Universitas Pamulang - Vol. 8, No. 2, Juli 2020 - Anwar \& Firmansyah

dimiliki oleh seluruh perusahaan yang umumnya berupa tandan buah segar. Daftar aset biologis setiap perusahaan secara lengkap disajikan pada lampiran 1 .

Perbandingan Akuntansi Agrikultur Sebelum dan Sesudah Berlakunya PSAK 69 dan Amandemen PSAK 16

a. Tanaman Tahunan

1) Tanaman Produktif/Bearer Plants

Dari empat belas perusahaan yang menjadi objek penelitian ini, seluruhnya memiliki tanaman produktif. Selain itu, terdapat beberapa tanaman produktif lain yaitu tanaman teh, kopi, kakao, tebu, hingga hutan tanaman industri yang ditumbuhi pohon kayu. Perlakuan akuntansi atas tanaman produktif diatur dalam PSAK 16 (IAI, 2015), yang merupakan adopsi dari IAS 16 amandemen 2014. Pada periode 2016 dan 2017, berdasarkan tabel 4.2 perbandingan pengakuan dan pengukuran aset biologis, dapat diketahui bahwa seluruh perusahaan telah menerapkan perlakuan akuntansi atas tanaman produktif yang sesuai dengan PSAK 16 amandemen 2014, kecuali PALM. Sementara itu, perusahaan yang memiliki tanaman tebu belum menerapkan perlakuan akuntansi atas tanaman tebu sesuai PSAK 16 (IAI, 2015). Dalam hal pengukuran, hampir semua perusahaan memilih menggunakan metode biaya. Hanya terdapat dua perusahaan yang memilih menggunakan metode revaluasi, yaitu GZCO dan PALM. Namun, terdapat ketidaksesuaian perlakuan akuntansi dengan PSAK 16 (IAI, 2015) yang dilakukan oleh PALM. PALM tidak melakukan penyusutan atas tanaman produktifnya, padahal PSAK 16 (IAI, 2015) mengharuskan perusahaan melakukan penyusutan atas asetnya meskipun menggunakan model revaluasi. Sementara itu, untuk tanaman tebu, perusahaan belum menerapkan perlakuan akuntansi yang sesuai dengan PSAK 16 (IAI, 2015) pada periode 2016 dan 2017. SIMP dan TBLA merupakan perusahaan yang memiliki tanaman tebu. SIMP mengakui tanaman tebu sebagai beban tanaman tebu ditangguhkan, sedangkan TBLA mengakui tanaman tebu sebagai persediaan. Pada periode ini, TBLA masih mengklasifikasikan tanaman tebu sebagai tanaman semusim, bukan tanaman tahunan.

Pada periode 2018, berlaku efektifnya amandemen PSAK 16 tidak memberikan dampak signifikan dalam perlakuan akuntansi tanaman produktif, karena sebagian besar tanaman produktif telah diperlakukan sesuai dengan PSAK 16 (IAI, 2015) sebelum amandemen PSAK tersebut berlaku efektif. Namun, terkait tanaman tebu, berlakunya PSAK 16 (IAI, 2015) membuat perusahaan mengakui tanaman tebu sebagai sebagai bagian aset tetap dan diperlakukan sama dengan tanaman produktif lainnya sesuai PSAK 16 (IAI, 2015). Pada periode 2018, TBLA tidak lagi mengklasifikasikan tanaman tebu sebagai tanaman semusim, melainkan sebagai tanaman tahunan. Hal tersebut dapat dilihat dengan diklasifikasikannya tanaman tebu oleh TBLA ke dalam tanaman produktif. Tidak terdapat pengungkapan atas alasan TBLA mengubah klasifikasi tanaman tebu dari kelompok tanaman semusim menjadi tanaman tahunan. Hal tersebut memang tidak disyaratkan dalam PSAK 16, tetapi dapat mengurangi informasi yang relevan karena apabila TBLA masih mengelompokkan tanaman tebu ke dalam tanaman semusim, tanaman tersebut 
Jurnal Ilmiah Akuntansi Universitas Pamulang - Vol. 8, No. 2, Juli 2020 - Anwar \& Firmansyah

diperlakukan sesuai dengan PSAK 69 (IAI, 2015). Dalam PSAK 16 (IAI, 2015) maupun PSAK 69 (IAI, 2015) sendiri tidak dijelaskan secara rinci mengenai pengelompokkan tanaman tahunan dan tanaman semusim beserta contohnya, sehingga dapat menyebabkan perusahaan salah mengelompokkan tanaman yang dimilikinya.

Dalam hal penyajian dan pengungkapan, tidak terdapat perbedaan signifikan antara sebelum dan sesudah berlaku efektifnya PSAK 16 (IAI, 2015). Secara keseluruhan, perusahaan telah melakukan pengungkapan sesuai dengan yang disyaratkan PSAK 16 (IAI, 2015), meskipun masih terdapat beberapa perusahaan yang belum sepenuhnya sesuai. Pengungkapan yang belum sesuai diantaranya dilakukan oleh GZCO dan PALM yang menerapkan model revaluasi atas tanaman produktifnya. Baik GZCO maupun PALM tidak menyajikan nilai bruto apabila aset tersebut dicatat dengan metode biaya, padahal hal tersebut disyaratkan sebagai pengungkapan tambahan bagi entitas yang memilih menggunakan model revaluasi. Pada periode 2018, setelah berlakunya PSAK 16 (IAI, 2015), justru terdapat beberapa pengurangan pengungkapan yang memang tidak disyaratkan, tetapi dapat mengurangi informasi yang berguna bagi stakeholder. Hal tersebut dilakukan oleh LSIP dan SIMP, di mana pada periode 2018 tidak lagi menyajikan saldo akun beserta mutasinya secara terpisah antara tanaman belum menghasilkan dan tanaman menghasilkan. Hal tersebut tidak disyaratkan dalam PSAK 16 (IAI, 2015), tetapi dapat mengurangi informasi yang berguna, di mana pengguna informasi akan kesulitan mengetahui saldo masing-masing dari tanaman yang belum dan sudah menghasilkan. Akan lebih baik apabila hal tersebut diatur dalam PSAK.

2) Tanaman yang dapat dikonsumsi/ consumable plants.

Berdasarkan lampiran 2 tabel daftar aset biologis dan produk agrikultur setiap perusahaan, terdapat dua perusahaan yang memiliki tanaman yang dapat dikonsumsi atau consumable plants, yaitu SIMP dan DSNG. Baik SIMP maupun DSNG memiliki consumable plants berupa hutan tanaman industri yang ditumbuhi pohon kayu. Tanaman yang dapat dikonsumsi tersebut masuk dalam ruang lingkup PSAK 69 (IAI, 2015). Consumable plants diakui sebagai aset biologis dan diukur pada nilai wajar dikurangi biaya untuk menjual atau net realizable value.

Sebelum berlakunya PSAK 69 (IAI, 2015), baik DSNG maupun SIMP, mengakui consumable biological plants berupa hutan tanaman industri sebagai hutan tanaman industri dalam pengembangan dan hutan tanaman industri siap panen. DSNG dan SIMP sama-sama mengukur hutan tanaman industri pada nilai perolehan. Berdasarkan tinjauan penulis atas perlakuan akuntansinya, DSNG dan SIMP mengacu pada DOLAPKE-PHP2H dalam memperlakukan hutan tanaman industri pada periode ini. Namun, terdapat perbedaan perlakuan antara DSNG dan SIMP, dimana DSNG melakukan penyusutan, sedangkan SIMP tidak melakukan penyusutan. Setelah berlakunya PSAK 69 (IAI, 2015), DSNG dan SIMP mengakui hutan tanaman industri yang ditumbuhi pohon kayu sebagai aset biologis. Berlakunya PSAK 69 memberikan dampak pada perubahan pengukuran dari nilai perolehan menjadi net realizable value. Perubahan pengukuran tersebut dapat berdampak pada relevansi informasi di 
Jurnal Ilmiah Akuntansi Universitas Pamulang - Vol. 8, No. 2, Juli 2020 - Anwar \& Firmansyah

mana nilai wajar suatu aset tertentu dianggap akan lebih berguna daripada nilai historis (Kieso et al., 2017). Pengukuran pada net realizable value juga dapat menimbulkan keuntungan atau kerugian akibat perubahan nilai tersebut. Selain itu, PSAK 69 juga berdampak pada keseragaman perlakuan akuntansi atas tanaman yang dapat dikonsumsi yang dimiliki perusahaan, khususnya hutan tanaman industri jenis consumable plants.

\section{b. Tanaman Semusim}

Pada periode 2018, hanya satu perusahaan dari objek penelitian yang memiliki tanaman semusim, yaitu ANJT. ANJT memiliki tanaman semusim berupa tanaman kacang edamame. Sebelumnya, TBLA sempat mengelompokkan salah satu jenis tanaman yang dimilikinya sebagai tanaman semusim, yaitu tanaman tebu. Namun, pada periode 2018 TBLA tidak lagi mengelompokkan tanaman tebu sebagai tanaman semusim, melainkan tanaman tahunan dalam kelompok tanaman produktif. Tanaman semusim merupakan aset biologis yang termasuk dalam ruang lingkup PSAK 69 (IAI, 2015). Tanaman semusim diukur sebesar nilai wajar dikurang biaya untuk menjual atau net realizable value. Sebelum berlaku efektifnya PSAK 69 (IAI, 2015), ANJT tidak mengakui dan mencatat tanaman kacang edamame ke dalam laporan keuangan. ANJT tidak melakukan penerapan dini PSAK 69 (IAI, 2015). Setelah berlaku efektifnya PSAK 69, ANJT mengakui dan mencatat tanaman kacang edamame yang diukur pada net realizable value. Berlakunya PSAK 69 (IAI, 2015) memberikan dampak pada laporan keuangan perusahaan dengan meningkatnya aset seiring pengakuan aset biologis. Selain itu, dengan pengukuran berdasar net realizable value, akan berdampak pula pada laba rugi perusahaan, dimana keuntungan atau kerugian akibat pengakuan awal aset biologis pada net realizable value atau perubahan net realizable value diakui dalam laba rugi periode berjalan. Terkait pengelompokkan tanaman semusim dan tanaman tahunan, akan lebih baik apabila PSAK memberi definisi atas kedua kelompok tersebut beserta kriteria dan contohnya. Hal tersebut akan memberi pedoman bagi perusahaan dalam pengelompokan dan menghindari kesalahan ataupun ketidakseragaman pengelompokan.

\section{c. Hewan}

Dari seluruh perusahaan yang dijadikan objek dalam penelitian ini, hanya AALI yang memiliki aset hewan dalam aktivitas agrikulturnya, yaitu berupa sapi ternak dan sapi bakalan. Hewan merupakan aset biologis yang termasuk dalam ruang lingkup PSAK 69 (IAI, 2015). Sebelum berlakunya PSAK 69 (IAI, 2015), tidak ada PSAK lain yang mengatur tentang perlakuan akuntansi atas hewan hidup yang digunakan dalam aktivitas agrikultur. AALI sebagai satu-satunya perusahaan dari objek penelitian yang memiliki aset hewan, tidak melakukan penerapan dini PSAK 69 (IAI, 2015). Sebelum berlaku efektifnya PSAK 69 (IAI, 2015), AALI telah mengakui aset hewan, tetapi diukur dengan biaya perolehan dan tidak disusutkan. Selain itu, aset hewan yang sudah tidak produktif direklasifikasi menjadi persediaan oleh AALI. Dengan berlaku efektifnya PSAK 69 (IAI, 2015), AALI mengubah dasar pengukuran aset hewan dari nilai perolehan menjadi net realizable value. Aset hewan diakui dalam akun aset biologis pada pos aset tidak 
Jurnal Ilmiah Akuntansi Universitas Pamulang - Vol. 8, No. 2, Juli 2020 - Anwar \& Firmansyah

lancar. Selain itu, aset hewan yang sudah tidak produktif tidak lagi direklasifikasi menjadi persediaan, melainkan tetap diakui dalam akun aset biologis dan disajikan dalam kelompok aset lancar. PSAK 69 (IAI, 2015) berdampak pada perubahan dasar pengukuran aset hewan. Perusahaan kini memiliki pedoman yang spesifik terkait aset hewan yang dimiliki. PSAK 69 (IAI, 2015) juga berdampak pada kebijakan terkait reklasifikasi aset hewan yang dimiliki perusahaan. Dalam hal pengungkapan, tidak terdapat dampak signifikan. Pengungkapan AALI terkait aset hewan hanya bertambah mengenai dasar penentuan nilai wajar, selebihnya tidak ada perbedaan terkait pengungkapan.

\section{d. Produk Agrikultur}

Seluruh perusahaan yang menjadi objek penelitian ini tentunya memiliki produk agrikultur sebagai hasil dari aktivitas agrikulturnya. Pada lampiran 2 tabel daftar aset biologis dan produk agrikultur setiap perusahaan, dapat dilihat bahwa tandan buah segar menjadi mayoritas produk agrikultur yang dimiliki oleh perusahaan. Selain itu, terdapat juga produk agrikultur berupa getah karet, produk sagu, dan sebagainya. Pada periode 2016 dan 2017, berdasarkan tabel lampiran 1 tabel perbandingan pengakuan dan pengukuran aset biolgis, dapat dilihat bahwa tidak ada satupun perusahaan yang menerapkan secara dini PSAK 69 (IAI, 2015) maupun mengacu pada IAS 41 amandemen 2014 dalam perlakuan akuntansi atas produk agrikulturnya. Pada periode 2016-2017 ini, seluruh perusahaan seragam tidak mengakui produk agrikultur sebagai aset dan tidak mencatatnya dalam laporan keuangan. Setelah berlau efektifnya PSAK 69 sejak 1 Januari 2018, barulah seluruh perusahaan mengakui produk agrikultur sebagai aset biologis dan diukur pada net realizable value. Keuntungan atau kerugian bersih akibat perubahan net realizable value diakui perusahaan dalam laba rugi periode berjalan. Perusahaan juga melakukan penyesuaian retrospektif atas penerapan PSAK 69 terkait aset biologis ini. Secara keseluruhan, seluruh perusahaan telah menerapkan perlakuan akuntansi atas produk agrikultur sesuai dengan PSAK 69 pada periode 2018, meskipun dalam hal pengungkapan terdapat beberapa perusahaan yang belum sesuai. Pengungkapan yang belum sesuai dilakukan oleh AALI dan GZCO. Baik AALI maupun GZCO tidak menyajikan rekonsiliasi atas saldo awal dan akhir produk agrikultur, padahal penyajian tersebut diharuskan oleh PSAK 69 (IAI, 2015).

PSAK 69 (IAI, 2015) berdampak pada pengakuan produk agrikultur sebagai aset biologis, yang sebelumnya tidak diakui sebagai aset dalam laporan keuangan oleh perusahaan. Pengakuan tersebut berdampak pada kenaikan jumlah aset yang diakui oleh perusahaan dalam laporan keuangan. PSAK 69 (IAI, 2015) memberikan pedoman bagi perusahaan dalam mengakui dan mengukur produk agrikultur. Pengakuan dan pengukuran tersebut sangatlah penting karena perusahaan subsektor perkebunan hampir dipastikan memiliki porduk agrikultur dalam jumlah yang material sebagai hasil aktivitas agrikulturnya. Penerapan PSAK 69 (IAI, 2015) juga berdampak pada pos laba rugi, dimana pengukuran pada net realizable value, dapat menimbulkan keuntungan atau kerugian yang diakui dalam laba rugi pada periode terjadinya. PSAK 69 (IAI, 2015) menyeragamkan 
Jurnal Ilmiah Akuntansi Universitas Pamulang - Vol. 8, No. 2, Juli 2020 - Anwar \& Firmansyah

perlakuan akuntansi seluruh perusahaan terkait pengakuan dan pengukuran atas produk agrikultur. Namun, dalam hal penyajian dan pengungkapan, masih terdapat perbedaan antar perusahaan meskipun tidak terlalu signifikan. Belum semua perusahaan yang melakukan penyajian dan pengungkapan sesuai dengan PSAK 69 (IAI, 2015).

\section{KESIMPULAN}

Berlaku efektifnya PSAK 69 (IAI, 2015) memberikan perubahan atau dampak yang signifikan terhadap perlakuan akuntansi atas aset biologis yang dimiliki perusahaan. Terutama terkait produk agrikultur yang dimiliki oleh seluruh perusahaan. Dengan berlaku efektifnya PSAK 69 (IAI, 2015), seluruh perusahaan akhirnya mengakui dan mencatat produk agrikultur yang dimilikinya sebagai aset biologis dan diukur pada net realizable value-nya, di mana sebelumnya tidak ada satupun perusahaan yang mengakui dan mencatat produk agrikultur. Hal tersebut berdampak pada laporan keuangan dengan ada peningkatan jumlah aset perusahaan. Selain itu, pengukuran pada net realizable value dapat memengaruhi laba rugi berjalan di mana pengakuan pada net realizable value maupun perubahan net realizable value menimbulkan keuntungan atau kerugian bagi perusahaan. Terkait aset hewan dan consumbale plants, berlaku efektifnya PSAK 69 (IAI, 2015) memberikan pedoman bagi perusahaan dalam perlakuan akuntansi atas aset hewan dan consumable plants yang utamanya terkait hutan tanaman industri. Berlakunya PSAK tersebut berdampak pada perubahan kebijakan pengukuran perusahaan atas consumable plants dan aset hewan menjadi net realizable value. Sebelumnya, perusahaan mengukur consumable plants dan aset hewan pada nilai historis. Hal tersebut dapat berdampak pada relevansi informasi nilai tanaman yang disajikan dalam laporan keuangan. PSAK 69 (IAI, 2015) juga memberikan dampak pada keseragaman atas consumable plants, dimana sebelumnya beberapa perusahaan yang memiliki tanaman ini berbeda dalam kebijakan akuntansinya. Dalam hal perlakuan akuntansi atas tanaman semusim, berlakunya PSAK 69 (IAI, 2015) memberikan dampak berupa penambahan jumlah aset seiring pengakuan tanaman semusim sebagai aset. Terkait tanaman tahunan kelompok tanaman produktif (bearer plants), tidak terdapat dampak perubahan yang signfikan atas berlaku efektifnya PSAK 16 (IAI, 2015) karena hampir seluruh perusahaan telah menerapkan perlakuan akuntansi yang sesuai sebelum berlaku efektifnya PSAK tersebut. Namun, dalam hal pengungkapan, justru pada periode 2018 terdapat pengurangan pengungkapan berupa tidak disajikannya mutasi saldo tanaman produktif secara terpisah antara tanaman belum menghasilkan dan tanaman menghasilkan oleh beberapa perusahaan. Pengungkapan tersebut memang tidak disyaratkan, tetapi dapat berpengaruh pada berkurangnya informasi yang berguna bagi pengguna laporan keuangan. 
Jurnal Ilmiah Akuntansi Universitas Pamulang - Vol. 8, No. 2, Juli 2020 - Anwar \& Firmansyah

\section{DAFTAR PUSTAKA}

Argiles, M. J., Garcia-Blandon, J., \& Monllau, T. (2011). Fair value versus historical cost-based valuation for predictability of financial information. Revista de Contabilidad-Spanish Accounting Review, 14(2), 87-113.

Badan Pusat Statistik (BPS). (2018). Ekonomi Indonesia Triwulan II-2018 Tumbuh 5,27

Persen.

(https://www.bps.go.id/pressrelease/2018/08/06/1521/ekonomi-indonesiatriwulan-ii-2018-tumbuh-5-27-persen, diakses pada 9 Desember 2018).

Bohusova, H., \& Svoboda, P. (2016). Biological assets: in what way should be measured by smes. Procedia - Social and Behavioral Sciences, 220, 62 - 69.

Detikfinance. 2009. Konvergensi IFRS Berlaku 2012.

(https://finance.detik.com/moneter/d-1138564/konvergensi-ifrs-berlaku2012, diakses pada 12 Desember 2018.

Elad, C., \& Herbohn, K. (2011). Implementing fair value accounting in the agricultural sector. Edinburgh: The Institute of Chartered Accountants of Scotland.

Farida, I. (2013). Analisis perlakuan aset biologis berdasarkan IAS 41 pada PT Perkebunan Nusantara VII (Persero). Universitas Negeri Surabaya, 1-24.

Hastuti, D. (2017). Ekonomika Agribisnis. Makassar: Rumah Buku Carabaca.

Ikatan Akuntan Indonesia. (2009). Dampak Konvergensi International Financia Reporting Standards (IFRS) terhadap Bisnis.

(http://iaiglobal.or.id/v03/berita-kegiatan/detailarsip-92, diakses tanggal 15 Mei 2019.

Ikatan Akuntan Indonesia. (2013). Laporan dari London-Malaysia: Revisi IAS 41 Susah Diaplikasikan.

http://iaiglobal.or.id/v03/berita-kegiatan/detailarsip-574, diakses pada 12 Desember 2018.

Ikatan Akuntan Indonesia. (2018). Standar Akuntansi Keuangan per Efektif 1 Januari 2018. Jakarta: Salemba Empat.

Julianto, Pramdia Arhando. (2017). Negara Agraris, Mengapa Harga Pangan di Indonesia Rawan Bergejolak.

https://ekonomi.kompas.com/read/2017/02/19/163912926/negara.agraris.m engapa.harga.pangan.di.indonesia.rawan.bergejolak, diakses pada 9 Desember 2018.

Kieso, D.E, Weygandt, Jerry.J, \& Warfield, Terry.D. (2017). Intermediate Accounting 3th Edition. USA: John Wiley \& Sons, Inc.

Listyawati, R., \& Firmansyah, A. (2018). Evaluasi penerapan akuntansi aset biologis pada perusahaan sektor peternakan. Substansi, 2(1), 59-76. 
Jurnal Ilmiah Akuntansi Universitas Pamulang - Vol. 8, No. 2, Juli 2020 - Anwar \& Firmansyah

Marta, M. F. (2017). Ironi Negeri Agraris dan Upaya Mereduksi Risiko Kredit Pangan.

https://ekonomi.kompas.com/read/2017/01/30/063000426/ironi.negeri.agra ris.dan.upaya.mereduksi.risiko.kredit.pangan, diakses pada 9 Desember 2018.

National Geographic. Tanpa Tahun. Agriculture.

https://www.nationalgeographic.org/encyclopedia/agriculture, diakses tanggal 12 Mei 2019.

Redaksi Wartaekonomi Online. (2017). LIPI: Masalah Utama Petani Itu Akses Sumber Pembiayaan.

https://www.wartaekonomi.co.id/read155075/lipi-masalah-utama-petaniitu-akses-ke-sumber-pembiayaan, diakses pada 9 Desember 2018.

Survei Angkatan Kerja Nasional (Sakernas). 2018. Penduduk 15 Tahun ke Atas yang Bekerja Menurut Lapangan Pekerjaan Utama 1986-2017.

https://www.bps.go.id/statictable/2009/04/16/970/penduduk-15-tahun-keatas-yang-bekerja-menurut-lapangan-pekerjaan-utama-1986---2018, diakses pada 9 Desember 2018.

Syafrezani, S. (2009). Manfaat Tumbuhan Bunga Penghias Pekarangan. Bandung: Titian Ilmu.

Peraturan Menteri Kehutanan Republik Indonesia, Nomor P.69/Menhut-II/2009 tentang Pedoman Pelaporan Keuangan Pemanfaatan Hutan Produksi dan Pengelolaan Hutan (DOLAPKEU-PHP2H). 